\title{
Lumen
}

Selected Proceedings from the Canadian Society for Eighteenth-Century Studies

\section{Credit and Credulity in Montesquieu's Lettres persanes}

\section{David McCallam}

Volume 29, 2010

URI : https://id.erudit.org/iderudit/1012029ar

DOI : https://doi.org/10.7202/1012029ar

Aller au sommaire du numéro

Éditeur(s)

Canadian Society for Eighteenth-Century Studies / Société canadienne d'étude du dix-huitième siècle

ISSN

1209-3696 (imprimé)

1927-8284 (numérique)

Découvrir la revue

Citer cet article

McCallam, D. (2010). Credit and Credulity in Montesquieu's Lettres persanes.

Lumen, 29, 107-116. https://doi.org/10.7202/1012029ar

Copyright (c) Canadian Society for Eighteenth-Century Studies / Sociéte canadienne d'étude du dix-huitième siècle, 2010
Ce document est protégé par la loi sur le droit d'auteur. L'utilisation des services d'Érudit (y compris la reproduction) est assujettie à sa politique d'utilisation que vous pouvez consulter en ligne.

https://apropos.erudit.org/fr/usagers/politique-dutilisation/ 


\section{Credit and Credulity in Montesquieu's Lettres persanes}

In early eighteenth-century France the concept of "crédulité" had largely negative connotations. As defined by the first edition of the Dictionnaire de l'Académie française in 1694, it constituted a certain "facilité à croire," the attribute of one who believed "trop facilement," and was thus an undesirable quality somewhere between naïvety and gullibility, most commonly associated with the ignorant masses. "Le peuple est crédule" was how one of the dictionary's illustrations of the adjective ran. ${ }^{1}$ For the Huguenot philosopher, Pierre Bayle, this popular credulity represented "une peste très-dangereuse aux societez" precisely because it was incapable of distinguishing true faith from mere superstition. ${ }^{2}$ The danger then lay in vulgar credulity anchoring itself in nothing other than the word of authority, making it the constant dupe of idolatrous Catholicism and intolerant absolutism.

While other revealed religions were also beset by popular credulity, it seems that for some French thinkers of the early eighteenth century the rich cultural and philosophical traditions of Islam did more than most to provide an alternative model of reason operating within a faith system, providing in the process an alternative, enlightened understanding of credulity. As Jonathan Israel has shown, with a renewed interest via Bayle, d'Argens and others in medieval Muslim philosophers such as Ibn Rushd (better known in the West as Averroes), Islam gained the reputation at this time of being a vehicle for the intelligent questioning

1 Le dictionnaire de l'Académie françoise, dédié au Roy, 2 vols. (Paris: Vve J. B. Coignard et J. B. Coignard, 1694), 1:289.

2 Pierre Bayle, Continuation des Pensées diverses sur le comète, 2 vols. (Rotterdam: 1705), $1: 8-8^{v}$. Cited in Jonathan I. Israel, Enlightenment Contested: Philosophy, Modernity and the Emancipation of Man 1670-1752 (Oxford: Oxford University Press, 2006), 77. 
of metaphysical truths, a place for the exercise of reason in faith. ${ }^{3}$ Hence Jean-Frédéric Bernard's Persian philosopher of his Réflexions morales of 1711 might still rail against the "gross" credulity of the superstitious masses, specifically denouncing their dependence on the fetishistic relics of their faith, but in doing so, he actively embodied a different form of credulity - individualist, tolerant, inquisitive, enlightening a belief in a critical Islamic morality that consistently sought to "peser le tout à la balance de la raison." ${ }^{\prime 4}$ In other words, his Persian traveller employs a universal reason to expose the inconsistencies between what Christianity preached (gentleness, love, submission) and what the Christian West did (indulge in sectarian war characterized by hatred and barbaric cruelty). ${ }^{5}$ Henri de Boulainvilliers similarly conflated critical reason and Islamic belief in his posthumous La Vie de Mahomed (1730), claiming that the Prophet's religious thought was entirely "plausible" and "conforme aux lumières de la raison." ${ }^{\text {"W }}$ What these interpreters of Islam were doing in early eighteenth-century France was to use "Mahométisme," as they erroneously called it, not just to denote the possibility of a reasoning tolerant faith, but also to connote a faith in the power of reason itself. This is what we might term a "good" credulity: a non-Christian willingness to believe used as an Enlightenment vehicle to criticize religious authority and the established political order. In the works of Bernard and Boulainvilliers - and, as will become apparent, in Montesquieu's Lettres persanes - Muslim credulity is employed as a faith in the work of reason, what Jacques Derrida calls "une foi hypercritique, sans dogme et sans religion, irréductible à toute institution religieuse ou implicitement théocratique." ${ }^{\prime 7}$ Faith and Reason are thus no longer the antithetical poles of early French Enlightenment thought. In fact, credulity becomes the very possibility of a belief in reason, or as Derrida says, "Cette foi est une autre façon de raison garder, si folle qu'elle paraisse." $^{8}$

3 Jonathan Israel, Enlightenment Contested, 615-39.

4 See Gustave L. Van Roosbroeck, Persian Letters before Montesquieu (New York: Publications of the Institute of French Studies, 1932), 139. This short study reproduces the text of the key "Persian" sections of Bernard's Réflexions morales.

5 Van Roosbroeck, Persian Letters before Montesquieu, 109-21.

6 Henri, comte de Boulainvilliers, La vie de Mahomed (Londres; Amsterdam: P. Humbert, 1730), 247.

7 Jacques Derrida, Voyous: Deux essais sur la raison (Paris: Galilée, 2003), 211.

8 Derrida, Voyous, 211 (his italics). 
The genius, however, of the Lettres persanes is not just to draw on this contemporary understanding of Islam as a rational, highly moral, tolerant faith, using it, like Bernard, solely to contrast the coherence of Muslim thought with Christian hypocrisy. Instead, Montesquieu doubles up this favourable reading of Islam with a critical portrait of the flipside of contemporary Islamic culture: the despotic state, that is, with the despotism of a Persian harem as the thinly veiled caricature of the worst authoritarian tendencies of French absolutism. In other words, he deploys the inquisitive, critical credulity of the Islamic faith against the despotic Islamic state. Montesquieu can do this because Usbek, the novel's principal protagonist, is a product of both systems at once: a Muslim rationalist and a Persian overlord, an Islamic philosopher abroad and an oriental despot at home. Caught in this religious and cultural double-bind, Usbek's credulity, his will to believe, leads him sincerely to question the mullahs about the arbitrary proscriptions of his faith against eating pork or touching cadavers, just as his earlier questioning of the arbitrary conventions of the Shah's court had earned him powerful enemies there and hastened his flight from Persia. ${ }^{9}$ Yet, once in France and confronted with the irrational prejudices and religious hypocrisy of Western society, this same credulity or will to believe also confirms Usbek in his Muslim faith and, perversely, consolidates the tyrannical rule he seeks to exert over his wives and eunuchs back home. Whether it be in matters of faith or those of state, or indeed in the confines of the harem, credulity founds the exercise of power; yet what the Lettres persanes make clear is that credulity increasingly allows for a critique of power too.

This brings us to the knotty problem of just what sort of regime one should believe in. As a proponent of Natural Law theory, Montesquieu believed that society was founded on mankind's innate sociability, its drive for mutual aid, security and concord, against natural vulnerability, weakness, insecurity and strife. However, unlike earlier Natural Law theorists, such as Samuel Pufendorf, Montesquieu did not claim that man's sociability was immutably decreed by God, but was rather a natural attribute. ${ }^{10}$ Moreover, he believed that the highest expression of this natural sociability was the establishment of a just society in which the common interest always took precedence over particular interests; a

9 Charles Louis de Secondat, baron de Montesquieu, Lettres persanes, ed. Paul Vernière (Paris: Garnier Frères, 1960), 41-42, 21-22 respectively. All further references are to this edition and are cited parenthetically.

10 On Pufendorf, see Israel, Enlightenment Contested, 194-95. 
precedence that fostered virtue in the community. And in the so-called "Troglodyte" letters of the Lettres persanes (28-37), Montesquieu gives a schematic presentation of social evolution in which justice is inevitably the fruit of virtuous living, but a justice which requires no a priori divine sanction. The Gods, in the plural, appear only belatedly to the Troglodytes (33) to ratify and affirm their just society, but not to found it. ${ }^{11}$ This presentation of the civilizing process, then, sets a certain distance between social justice and the transcendental divine tradition on which credulity commonly draws. In this much, it raises the question: what force or authority exists to make the citizens believe in justice as a social ideal?

This is an important point for Montesquieu because he is aware that reason alone cannot persuade the vulgar populace to strive for justice. As the first edition of the novel in 1721 dismissively puts it, "le peuple est un animal qui voit et qui entend, mais qui ne pense jamais" (379). ${ }^{12}$ Hence, he maintains that certain metaphysical, hierarchical principles or concepts are required both to ground and to guide popular, ignorant credulity in upholding the moral and legal social order and in working toward a just society. These principles or concepts are things like God, Heaven, Hell, etc., transcendental signifiers that are presumed to exist outside of any system of meaning but are necessarily posited in order to secure meaning within that system. This explains in large part why in Letter LXXXIII Montesquieu identifies justice as an inherent quality of both men and God in an attempt, as Christopher Betts puts it, to confer "transcendent status on the ideal of justice" through its identification with the divine. ${ }^{13}$ Usbek writes: "S'il y a un Dieu [...] il faut nécessairement qu'il soit juste" (174). Without this transcendental sanction, "Justice", described in the same letter as "un rapport de convenance, qui se trouve réellement entre deux choses" (ibid), would become only "Justesse," not the social ideal of "équité" (175) but a mere equivalence of things, for example, the appropriateness of a given punishment to a given crime.

However, the problem for Montesquieu is that in early eighteenthcentury France this transcendental sanction is applied not so much to justice as a social ideal but to kingship as a political office. What is transcendent here is not what is "juste" but what is sovereign, and

11 See Diana J. Schaub, Erotic Liberalism: Women and Revolution in Montesquieu's Persian Letters (Lanham, Md.: Rowman \& Littlefield, 1995), 34.

12 This remark was, interestingly, removed from the 1754 edition.

13 Christopher Betts, Montesquieu: Lettres persanes (London: Grant \& Cutler, 1994), 53. 
that means whatever or whoever embodies sovereign power: the Pope, Louis XIV, even Usbek in his harem. All are transcendental signifiers of sovereignty. All are transcendent because their sovereignty constitutes a law outside of the law, a law that founds all laws, but which is also beyond their jurisdiction; it is, as Carl Schmitt claims, the right not just to found all other rights but also to suspend them indefinitely. ${ }^{14}$ Transcendent sovereignty is thus equally the basis of just government (in founding all rights) and despotism (in suspending them indefinitely). And for Montesquieu, the danger identified in French absolutism is precisely that of its sovereign power sliding imperceptibly into despotic rule $(55-56,185)$. This insight of the Lettres persanes was, of course, to be developed at length in Montesquieu's later works in which he spells out that sovereignty does not and cannot belong to the monarch alone. Instead, drawing in part on Boulainvilliers's "thèse nobiliaire," ${ }^{\prime 15}$ he takes the bold step of dropping the indivisible unity of sovereignty, positing in its stead modern monarchy as a dual system of government, combining kingship with intermediate, subordinate and dependent powers in the hands of the nobility. In Montesquieu's vision, neither nobles nor the monarch grew to power at the expense of the other's claims on sovereignty, and hence both remain - ideally - equal elements in a mixed monarchical government. ${ }^{16}$

The key point here is Montesquieu's principled contention, which is little more than a recommendation in the Lettres persanes, that sovereignty is divisible. However, it would be wrong to think that its divisibility means that sovereignty is transferrable. This is precisely the confusion present in French absolutism which is only absolute, that is, entirely concentrated in the hands of the king, in principle. In practice, absolutism is not only threatened with a slide into despotism but also

14 Carl Schmitt, Political theology: four chapters on the concept of sovereignty, trans. George Schwab (Cambridge, Mass.: MIT Press, 1985), 7: "Although [the sovereign] stands outside the normally valid legal system, he nevertheless belongs to it, for it is he who must decide whether the constitution needs to be suspended in its entirety"; and, 9: "The authority to suspend valid law - be it in a general or a specific case - is so much the actual mark of sovereignty."

15 On Boulainvilliers, see Harold Ellis, Boulainvilliers and the French Monarchy: Aristocratic Politics in Early Eighteenth-Century France (Ithaca, N.Y.: Cornell University Press, 1988), especially 76-84, 90-91.

16 See Michael Sonenscher, Before the Deluge: Public Debt, Inequality, and the Intellectual Origins of the French Revolution (Princeton: Princeton University Press, 2007), 138. For an early defence of this position in which Montesquieu draws, albeit confusedly, on a British model of monarchy, see Lettres persanes, 215-17. 
with an abdication of power on the part of the king to a supreme First Minister (a Richelieu, Mazarin, Law or Dubois), with power displaced unnaturally into what Montesquieu's contemporary, Charles-Irénée Castel, abbé de Saint-Pierre, calls a "grand vizirate,"17 a term necessarily evoking a form of delegated oriental despotism. Wittingly or unwittingly, Montesquieu illustrates this point in the form of the proxy despotism exercised by the denatured eunuchs in Usbek's seraglio. They, in turn, illustrate how ineffective and arbitrary a form of government this is. Nonetheless, the nature of sovereign power presents a very real political conundrum for the Regent and his regime on the death of Louis XIV. On the one hand, the old king's death can be seen as good insofar as it lifts the immediate threat of absolutism defaulting into despotism and allows for an empowering of intermediate bodies such as the Parlements and the seven newly formed "Conseils d'État". It can be seen as bad, however, insofar as the Regent himself only exercises sovereignty indirectly, in the name of the minor Louis $\mathrm{XV}$ - a precarious, vulnerable situation revealed by the young king's brush with death in 1718 at precisely the same time as his narrow escape from the murderous Cellamare conspiracy (a plot transposed to an oriental setting in Letter CXXVI). The problem, it would seem, with the Regency is not that it has divided sovereignty but that it has evacuated it of its transcendent force, eclipsing its transcendent signifier in the person of the young monarch. Hence its attempts at mixed government result only in a powerless pluralism. In this light, the polysynody of the Regency fails for the same reason that the polygamy of the harem fails: for want of a transcendental signifier of sovereignty, be it the underage monarch or the absent master, Usbek.

So what effect does all this have on our understanding of credulity? We might recall that, for Montesquieu, popular credulity required transcendental signifiers in order to be grounded and guided; yet with the evacuation of transcendental sovereignty under a sometimes frivolous and dissolute Regency, this popular credulity too loses its way and is no longer capable of striving for a just society. In this state, the people become the dupe of immanent social forces, especially the immanent belief systems constructed on social reputation and financial speculation. In other words, credulity degenerates into systems of credit, whether this credit be the "consideration" invested in social stereotypes and satirized relentlessly by Rica, or the paper banknotes of Law's Sys-

17 Cited in Orest Ranum, "Personality and Politics in the Persian Letters," Political Science Quarterly 84:4 (Dec. 1969): 619. 
tem denounced ferociously by both Rica and Usbek. In the case of both credit systems - social reputation and financial speculation - there is a basic lack of foundation, that is to say, a lack of any ultimate source of transcendental signification. Usbek's critique of a tax-farmer, a "directeur de conscience," a poet and an adventurer (99-104) just like Rica's portraits of "le Décisionnaire" (155-56), "les Diseurs de rien" (173), and especially "le Visiteur" (183-84) all reveal vain, ridiculous social types without greater moral purpose, principle or meaning than to be approved of, to be confirmed in their existence, by those who see and hear them socially. If they are "caractères" à la La Bruyère, they lack the immutable essence of the moralist's subjects ("le fat," "l'avare," "la coquette," etc.) which gives these their truth value and a transcendental signification beyond their individual existence. In the Lettres persanes we have moved away from the psychological certainties of characterology into the world of sociological uncertainty. Montesquieu's "caractères" are precisely without character, without ethos; they are no more than their puffed-up reputations, reputations which are no longer the result of inherent character traits but which are shaped and maintained by the good or bad opinions and beliefs that others have of them, specifically by the capricious empire of women in society ruling "comme un nouvel État dans l'État," as Rica describes it (224). ${ }^{18}$ In this way, these superficial creatures are like John Law's paper credit, itself without foundation, since its hugely inflated values are the product of an unconsidered overissuing of banknotes and the unbridled speculation in the shares of the state-bank-rolled Compagnie des Indes well beyond the bullion reserves of the bank on which both the issue of notes and the share options were supposedly based. ${ }^{19}$ Again Montesquieu decries a puffed-up credit system without real (that is, transcendental) foundation. Hence France is ripe for both moral and economic collapse. Its two credit "bubbles," social and economic, are ready to burst. And burst they do.

Where a study of credulity in the Lettres persanes is instructive here is in showing how a willingness to believe the word of others (the common basis of social reputation and financial speculation) can lead to ruin on a massive scale. That is, it reveals clearly how a will to believe,

18 Another distinction here emerges between credulity and credit: the former valorizes the sincerity of the speaker whereas the latter sets greater store by the reception of what is said. On Montesquieu and the value of sincerity, see Céline Spector, Montesquieu: Les "Lettres persanes" (Paris: PUF, 1997), 24, 66.

19 Jeremy Black, Eighteenth-Century Europe, $2^{\text {nd }}$ ed. (London: Macmillan, 1999), 73. 
how credulity itself is abused; or in the context of the Regency, it might be better to say, how credulity is "debauched." As the Persians' letters indicate, the first belief system to be debauched in Regency France is that of personal esteem and moral self-worth in a society governed by women's value judgements, in which the general tone of all discourse is reduced to flirtatious "badinage" (131), in which those who speak most and make least sense are adored by their female audience, creating an empire of "petits talents" (173) where the worthless seducer is "plus considéré qu'un grave magistrat" (103) simply because he has the gift of pleasing the opposite sex. In such as society ruled by women "en détail" as well as "en gros" (225), it is no longer what one believes which counts, but what others believe about oneself which dictates one's social fortunes. "Good" credulity (an enlightened openness to believe) is thereby replaced by "bad" credulity (slavishly following the advice and authority of others), and "considération" is duly shown to those who do not deserve it, who lack the character worthy of it. It is a similar tale of "debauchery" in the economic sphere in which Law's paper money debases or depreciates the state currency. Without the capital reserves to back it up, speculation in both shares and in paper banknotes leads to greed-fuelled boom followed by a panic-induced crash, precipitating a run on the Banque Royale with investors desperately trying to withdraw their rapidly depreciating funds, thereby destabilizing the whole economic system. As John Maynard Keynes (the advocate of a later mixed system of socio-economic governance) was to put it in the 1920s: "There is no subtler, no surer means of overturning the existing basis of society than to debauch the currency. The process engages all the hidden forces of economic law on the side of destruction." ${ }^{20}$ And for Montesquieu, as the Lettres persanes make patently clear, this is precisely what John Law did to the French economy $(279-80,293,321)$ : he debauched the currency. Hence all the transcendental signifiers upon which credulity, trust or belief might be founded (character, gold) are debauched into forms of credit ("considération," paper money).

In such a society, debauchery is far from being purely metaphorical. The notorious coterie of roués who surrounded the Regent flaunted their vice-ridden, corrupt lifestyles with impunity, seemingly immune to judicial or moral sanction. The lesson Montesquieu seems to draw

20 John Maynard Keynes, The Economic Consequences of the Peace (London: Labour Research Department, 1920), 220-21 (my italics). Cited in Naomi Klein, The Shock Doctrine: The Rise of Disaster Capitalism (Toronto: Alfred A. Knopf, 2007), 171. 
from this is that when sovereignty has been evacuated of its transcendent power, and the law it supposedly founds no longer holds sway, debauchery is not just the means by which public morality is dissolved, but also its ultimate endpoint. It is as if he is saying that without the transcendental sanction of sovereignty, the only civil liberty is libertinage. The fate of Usbek's seraglio tells a similar tale: debauchery occurs when the transcendental signifier (Usbek himself in this instance) is removed. And here too credulity - the women and eunuch's will to believe in the harem system - degenerates into forms of credit, into simulacra of belief, into ever-increasing violence as a display of the eunuchs' loyalty or into false flattery and hypocritical praise as an expression of the wives' love.

For Montesquieu, the damning common dynamic of all these credit systems is circulation without production. Parisian social butterflies, such as the archetypal "Visiteur" flit from hotel to hotel, from birth to birth, funeral procession to royal "lever" without being of any use to society at all; the "billets de monnaie" of Law's system pass feverishly from hand to hand without being assimilated to anything of durable value, the measure only of fabulous, ephemeral reversals of fortune; and, with one exception, the women of the harem succeed one another in Usbek's bed without producing any children. ${ }^{21}$ All that is generated is inflated reputations, short-lived fortunes, and vain passions; there is no individual virtue, no national prosperity, no progeny. All is flurry, activity, circulation, without production. Little wonder that Montesquieu's favoured image for this was that of wind, of hot air, of a France that Law's system "a rendue bouffie" (293), an image reprised and expanded in his comic transposition of Law's system into Fénelon's fabled kingdom of Betica where the Scottish adventurer manages to sell the people gourds full of wind in exchange for their gold and hard currency (307-10). More seriously, the same dynamic of circulation without production can also be seen as informing Usbek's long run of letters on the terrible processes of depopulation (232-59).

However, in conclusion, I would argue that the Lettres persanes also offer an alternative to these systems of credit, one which affords the reader an alternative model of credulity too. That alternative model is the letters themselves. Usbek and Rica's various correspondences

21 The exception is Zélis who writes to Usbek about their daughter, albeit to tell him that she is confining the girl to the strict claustration of the harem from her seventh year, and not her tenth, as was the custom (129). The only product of the seraglio is thus consigned, self-defeatingly, to circulate unproductively among other women and eunuchs. 
escape the traps of vulgar credulity by not simply believing what they are told and repeating it, but by sifting the appearances and information that they are presented with to form their own truths. They do not trade in the state-sponsored credit of academicians or Sorbonne doctors, or in the rumour-mongering credulity of the "nouvellistes"; rather, they are like Rica perusing the written word in a well-stocked Parisian library, determining what Christopher Betts calls "the proper use of human reason." ${ }^{\prime 2}$ In the Persians' observations and reflections, the rational, tolerant credulity associated with their Muslim faith is employed by Montesquieu to ground a new faith in reason. At once critical and credulous, Usbek and Rica open the way to a more secular future by using the very language of religious orthodoxy to expose the bankrupt credit systems of contemporary France. In this sense, the letters of the Lettres persanes represent the very opposite of Law's depreciated banknotes; they are paper currency of enduring value.

DAVID MCCALLAM

University of Sheffield, UK 